\title{
Stralingsprosessering in Suid-Afrika*
}

Die gebruik van radioaktiewe isotope in die nywerheid en geneeskunde het sedert die totstandkoming van die RAK in 1959, in Suid-Afrika met rasse skrede toegeneem sodat daar vandag sowat 1000 gemagtigde gebruikers van radioaktiewe isotope in Suid-Afrika is.

Alhoewel mediese naalde reeds al in 1966 op Pelindaba gesteriliseer is, kan die aanvang van gammasterilisering van wegdoenbare mediese produkte teruggevoer word tot'n versoek van die maatskappy Ethnor, in 1968, om chirurgiese hegmateriaal met straling te steriliseer. Vir die eerste drie jaar is 'n gammabestralingsdiens op 'n kontrakgrondslag in 'n navorsingsbestraler uitgevoer. Dit het egter spoedig geblyk dat hierdie bestraler se bestralingstyd nie voldoende was vir beide navorsing en kontrakbestraling nie, en het die Raad op Atoomkrag in 1970 die belangrike besluit geneem om 'n gammabestraler met 'n maksimum vermoë van 1,0 MCi vir diensbestralings op Pelindaba op te rig. Hierdie besluit en die oprigting van die JS 6500 -bestraler met 'n aanvanklike lading van $50 \mathrm{kCi}$ in 1971, kan inderdaad as die hoeksteen van die stralingsnywerheid in Suid-Afrika beskou word.

Gedurende die eerste jaar van bedryf (1971/1972) is ' $n$ totaal van 20,4 ton mediese produkte in 912 kartonne vir slegs twee gebruikers gesteriliseer. Hierdie syfer het gegroei totdat die laaste jaar van bedryf op Pelindaba (1979/1980) met 'n jaarlikse deurvoer van 1594 ton in 118000 kartonne vir meer as vyftig gebruikers afgesluit is - 'n merkwaardige groeikoers.

Daar kan vermeld word dat 'n totaal van 13400 kWh stralingsenergie gedurende 1980/81 vir stralingsprosessering in Suid-Afrika gebruik is - hoofsaaklik vir stralingsterilisering - gelykstaande aan die energie wat deur 'n elektriese toestel van $10 \mathrm{~kW}$ in sowat 60 dae verbruik sal word.

Deur hierdie gammabestralingsdiens het die Raad op Atoomkrag verseker dat Suid-Afrika 'n leiersrol op die gebied van gammaprosessering bereik het en is die besondere voordele wat gammasterilisering vir die land se gesondheidsdienste inhou, op 'n betroubare en ekonomies aantreklike wyse vir die plaaslike nywerhede beskikbaar gestel, en is 'n groot bydrae gelewer om die uitvoer van plaaslik vervaardigde mediese toerusting te bevorder.

Die besonder mooi groei wat gammaprosessering

\footnotetext{
*Uittreksel uit 'n toespraak gelewer deur dr. J.W.L. de Villiers, President van RAK tydens die opening van die Iso-Ster se bestralingsaanleg te Isando, 28 Oktober 1981.
}

op Pelindaba ondergaan het, het dan ook daartoe gelei dat die privaatsektor, in opvolging van 'n ondersoek wat die Nywerheid-ontwikkelingskorporasie uitgevoer het, besluit het om 'n kommersiële gammabestraler op te rig. Die gammabestraler met 'n maksimum vermoë van $6 \mathrm{MCi}$ wat deur Iso-Ster in bedryf gestel is, is die gammabestraler met die grootste vermoe twat nog ontwerp is. Dit bring mee dat hierdie bestraler ses keer meer produkte as die eerste bestraler op Pelindaba kan hanteer.

Ook op ander gebiede van stralingsprosessering word goeie vordering gemaak en 'n $3 \mathrm{MeV}$-elektronversneller vir elektronprosessering is ook gedurende hierdie jaar in bedryf gestel.

Die ontwikkeling van gammagekruisbinde kabelisolering deur die Raad op Atoomkrag in samewerking met AECI, het daartoe bygedra dat Suid-Afrika in 'n groot mate onafhanklik van hierdie strategiese materiaal kon raak. Hierdie nederige begin van kabelkruisbinding met gammastraling is besig om 'n besonder mooi groei te toon en dit kan inderdaad een van die belangrike en groot aanwendings van gammastraling in die toekoms word.

Op die gebied van voedselpreservering deur gammabestralíng lyk die toekoms ook baie belowend. Met die gunstige ontwikkelings op die gebied van internasionale vrystelling van bestraalde voedsel, wil ek my verstout om te sê dat voedselbestraling moontlik die grootste afsetgebied vir gammastraling sal bied.

\section{Simposium oor Bestuur in Navorsingsinrigtings: 6 Oktober 1981}

K.E. Ducat, Administratiewe- en Regsadviseur: Raad vir Mineraaltegnologie, Privaatsak X3015, Randburg

Dit is vreemd, maar nogtans 'n feit, dat daar tot dusver in Suid-Afrika met sy gevorderde navorsingskennis en -tegnieke, en sy talle inrigtings en laboratoria in die openbare sowel as die privaatsektor, min of geen simposia of konferensies oor die bestuur van sulke instellings gehou is nie.

Die gebrek aan kommunikasie op hierdie gebied het dr. Louw Alberts, President van die Nasionale Instituut vir Metallurgie in Randburg, gehinder en hy het besluit om nog voor die einde van 1981 'n konferensie 
te teël waar 'alle belanghebbendes hulle kennis kon uitruil en gedagtes kon wissel.

- Hy het toe sy voorstelle metidie Kámer van Mynwese bespreek en die Kamer het dit entoesiasties verwelkom.' 'n Komitee bestaande uit verteenwoordigers van NIM en die Kamer is saamgestel om die nodige reëlings te tref.

Die Komitee het vooraanstaande persone in die industrie en by staatsinrigtings genader en hulle het met graagte ingewillig om aan die program deel te neem.

Die simposium het op 6 Oktober 1981 plaasgevind en die belangstelling wat dit gewek het, kan uit die bywoningsyfer van 283 afgelei word.

Dr. Alberts het die besprekings ingelei met 'n referaat oor Research management by objectives. Hy het beklemtoon dat wetenskaplike en tegniese navorsing duur ondernemings word wat sowel bestuur as gelei moet word. 'n Navorsings- en ontwikkelingsorganisasie behoort nie ondoeltreffendheid of ontoepaslikheid te duld nie, ongeag of dit onder openbare of private beskerming optree. Sy werklike waarde word uiteindelik bepaal deur die uitwerking wat hy op sy omgewing het. Dit is beter dm die regte dinge te doen as om bloot net dinge reg te doen?

Die duidelike omskrywing en vasstelling van mikpunte vorm die kern van die stelsel van doelwitbestuur. Hierdie stelsel gee aan die navorsingsinrigtings 'n diepe sin van doelgerigtheid en rigting wat noodsaaklik is vir' effektiewe beplanning en beheer. Prestasiestandaarde, met inagneming van koste, mannekrag, waardebepaling, terugvoering en verbetering, volg as ' $t$ ware vanself as die beginsel van 'n resultategeoriënteerde bestuurstelsel eers aanvaar is. Bestuur volgens mikpunte is 'n deelnemingsbestuurstelsel wat lei tot radiale desentralisasie en selfbeheer deur die individu eerder as voorgeskrewe beheer. As dit verstandig en met die nodige respek vir skeppingswerk toegepas word, kan dit die arbeidsvreugde van die navorser asook die algehele produktiwiteit van die navorsingsinrigting verhoog.

Die tweede spreker was Sy Edele prof. E.J. Marais, Voorsitter van die Wetenskapskomitee van die Presidentsraad, wat oor Die struktuur en grootte van navorsingsorganisasies met betrekking tot program en omgening gepraat het. Hy was van mening dat die wetenskap die belangrikste beïnvloedende faktor in kultuurvorming is en eintlik die omgewing skep waarin die moderne mens leef.

Prof: Marais was bekommerd oor die fragmentasie in die wetenskap wat deur groter spesialisasie veroorsaak word. Die student kom nie by die belangrike kultuurbou waar hy as ingeligte, gevormde en gebalanseerde leier moet optree nie. Universiteite behoort die sintese te vind om tegelyk spesialiste en kultuurmense te vorm.

Hy het verder verwys na die noodsaaklikheid daárvan om optimaal gebruik te maak van beperkte finansiële en menslike hulpbronne. Doelgerigtheid en doeltreffendheid moet in navorsingsinrigtings ingebdu word en kriteria moet ontwikkel word om te bepaal watter projekte aangepak en watter uitgeskakel moet word. Hy het aanbeveel dat projekgroepe gestig word om navorsing te doen onder 'n groepleier wat bygestaan word deur spesialiste uit verskeie departemente.

In sy referaat het dr. R.E. Robinson, Senior Hoofbestuurder van Sentrachem, oor navorsingsbeplanning en projekseleksie in die chemiese nywerheid gepraat. Sy firma gebruik verdiskonteerde kontantvloeianalise by die keuring van projekte. Die hoë risikofaktor in die chemiese bedryf bring egter mee dat ' $n$ verdere tegniek bygevoeg moet word; naamlik waarskynlikheidsinflasie. Dit beteken dat die resultaat wat deur verdiskonteerde kontantvloei bereik word, deur die waarskynlikheidsinflasiefaktor aangepas word. Elke projek moet in sy verskillende stadiums geëvalueer word om die waarskynlikheid van sukses te bepaal. Die navorser moet ook die verwagte voordele en die koste van sy projek gereeld in oënskou neem.

Prof. D.H. Jacobson, Vise-president van die WNNR, het die uiters relevante punt geopper dat dit verkeerd sou wees om die huidige begroting uit staatsfondse konstant te hou, bloot omdat daar nie genoeg navorsers is om die bewilliging van bykomende fondse te regverdig nie. Die Republiek moet maak soos in die sestigerjare in die VSA gedoen is: navorsingsbegrotings moet verhoog word, opleidings- en navorsingsfasiliteite by universiteite moet uitgebrei word en die modernste toerusting'moet aangekoop word. Sodoende sal hoogsgeskoolde persone van die beste gehalte na die navorsingsektor getrek word en sal Suid-Afrika 'n ongekende bloeitydperk op wetenskaplike gebied beleef.

Die doel van navorsing in die mynboubedryf is om probleme op te los. Probleme word geïdentifiseer en slegs dié wat as van groot gemeenskaplike belang vir die bedryf beskou word, word ondersoek. 'n Suksesvolle projek gaan gewoonlik deur vyf stadiums: navorsing, ontwikkeling, evaluasie, veldproewe en implementering. Die vooruitgang van 'n projek, die kanse om sukses te behaal, en die koste daarvan, moet noukeurig dopgehou word. Hierdie stellings is deur professor M.D.G. Salamon, dr. A.C. Lawrence en dr. N.C. Joughin van die Kamer'van Mynwese gemaak.

'n Referaat oor die keuring, bestuur en administrasie van navorsingsprojekte by die Nasionale Instituut vir Metallurgie is deur mnre. H.E. James en P.J. Steenkamp aangebied. Hierdie praktiese uiteensetting het aan die afgevaardigdes ' $n$ beeld gegee van die stelsel wat NIM oor die jare ontwikkel het. Die primêre doelwit van NIM is om navorsingswerk vir die SuidAfrikaanse mineralebedryf as 'n geheel te doen, waarby die nasionale ekonomie uiteindelik sal baat. Die sukses wat NIM met hierdie oogmerke behaal het en sy reputasie as ' $n$-leier op die gebied van ekstraksiemetallurgiese navorsing, is in 'n hoë mate aan sy doeltreffende projekbeheerstelsel te danke. Die stelsel is gebaseer op die volgende beginsels wat die bestuur van navorsing by NIM ten grondslag lê:

(1) 'n vasbeslote strewe na duidelik omskrewe doelwitte vir elke navorsingsprojek;

(2) die besef dat geen enkele navorser die nodige kundigheid het om alleen 'n idee in die werklikheid te 
omskep nie; derhalwe is uiters dissiplinêre spanwerk 'n noodsaaklikheid;

(3) noukeurige omskrywing van 'n projek sodat 'n redelike skatting van die voordele gemaak kan word;

(4) 'n positiewe plan vir dic opeenvolgende stappe wat gedoen moet word, en 'n diensrooster;

(5) 'n omskrywing van ander bedrywighede wat saam met die hoofaktiwiteite uitgevoer moet word en die bepaling van datums waarop kritieke besluite geneem moet word;

(6) bepaling van die dienste wat nodig sal wees;

(7) noue samewerking tussen die navorser en die borg ten einde goeie tegnologie-oordrag te verseker.

NIM gebruik 'n kombinasie van 'n afdelingsbestuurstelsel en 'n matriksbestuurstelsel vir die onderneem van projekte: die projekleier bly onder die beheer van sy eie afdelingshoof, maar hy kan van die personeel en dienste van ander afdelings gebruik maak.

'n Projekkaart waarvan die ontwerp eie aan NIM is, word vir elke projek gebruik. Daarin word die stappe, die beoogde teikendatums, die besluitpunte en die bykomende dienste wat nodig sal wees, uiteengesit en die projekadministrasieseksie sorg dat enige afwyking van die rooster onder die aandag van die projekleier en die betrokke bestuurslede gebring word.

Volgens dr. G.S. Harrison, Tegniese Bestuurder van AECI Beperk, het sy maatskappy 'n navorsingsdepartement wat in groepe onderverdeel is. Die groepe vir die verskeie afdelings staan onder die beheer van groepleiers en daar is ook sentrale groepe wat na probleme van die firma as 'n geheel kyk. Die groepleier is verantwoordelik vir die navorsing op sy eie gebied en moet ' $n$ vyfjaarprogram opstel wat hy elke jaar moet byhou. Daarby moet hy 'n gedetailleerde plan vir die volgende jaar opstel. Al hierdie planne word in oorleg met die ander afdelings, en veral met die produksie- en bemarkingsfunksies, opgestel. Die planne in die algemeen en die vordering daarmee word gereeld deur die Uitvoerende Komitee in oënskou geneem.

In sy referaat het dr. J.W.L. de Villiers, President van die Raad op Atoomkrag, veral klem gelê op die keuring en bestuur van projekte by die RAK. Elke projek moet gemotiveer word en die motivering moet volle besonderhede van die doelstelling, die begroting, bedryfsuitgawes, tydsduur en totale beraamde koste van die projek verstrek.

Dr. A. Brink, Assistent-hoof bestuurder van Sasol, het oor die oordrag van tegnologie tussen die navorsings-, ontwikkelings- en produksiedepartemente by Sasol gepraat. Die navorsingsdepartement moet eers 'n uitvoerbaarheidstudie doen om te sien of 'n projek 'n goeie kans op sukses het. Indien wel, moet die ander twee departemente dan betrek word om doelwitte, programme en roosters op te stel. Wanneer 'n projek 'n stadium bereik waar dit suksesvol blyk te wees, moet dit aan die produksiedepartement oorhandig word, maar die ander twee moet nie hulle taak as afgehandel beskou nie - daar kan nog probleme opduik waar hulle dienste nodig sal wees.

By die Uraanverrykingskorporasie (Ukor) moes 'n sisteem ontwikkel word om die bevredigende oordrag van tegnologie te verseker. Die probleme was eintlik dat 'n hele aantal dissiplines betrokke was, die besondere kundigheid meesal intern ontwikkel moes word en dat daar 'n landswye tekort aan gespesialiseerde personeel was. In sy referaat beskryf dr. R.S. Loubser, Senior Hoofbestuurder van Ukor, hoe kleiner projekte onder sterk projekleiding met geïntegreerde spanne gehanteer word terwyl groter projekte op 'n matriksgrondslag en met die invoer van kundigheid uit ander funksies, gehanteer word.

'n Referaat oor die implementering van vordering op die gebied van die mynboubedryf is deur drr. $\mathrm{H}$. Wagner en P.J.D. Lloyd, albei van die Kamer van Mynwese, gelewer. Volgens hulle is dit makliker om nuwe mynontwerpkonsepte en dienstoerusting in bedryf te stel as om nuwe produksietegnologie te implementeer. Dit is moontlik omdat daar in die laasgenoemde geval drie groepe betrokke is - die uitvindergroep, die vervaardigingsgroep en die gebruiksgroep. Die uitvinder moet kennis dra van die behoeftes van beide die fabrikant en die verbruiker, die fabrikant moet die behoeftes van die verbruiker begryp en die verbruiker moet bereid en in staat wees om sy mynboustelsel en -organisasie by die nuwe toerusting aan te pas.

Mnr. M.D. Kingwill, Direkteur, Inligting en Navorsingsdienste, WNNR, het die volgende boodskap vir die simposiumgangers gehad: Sukses met tegnologiese vernuwing hang af van die sorg waarmee doelwitte omskryf word en realistiese daarstelling van navorsing en ontwikkeling in terme van daardie doelwitte.

Die referaat van dr. A.P. Burger, Hoof van Wetenskapbeplanning in die Kantoor van die Eerste Minister, het een belangrike kenmerk in die besoldigingstruktuur vir navorsers in die owerheidsektor uitgelig. Dit is ,dat, afgesien van die feit dat inkomstes in die owerheidsektor op alle vlakke heelwat laer as dié op die ooreenkomstige vlak in die privaatsektor is, die salarishelling in die owerheidsektor ' $n$ besondere gedrag toon in teenstelling met die privaatsektor. Terwyl die helling vir die laer-en middelinkomstegroepe naamlik vergelykbaar met dié in die privaatsektor is, buig dit in die senior poste dramaties af tot ' $n$ besonder lae waarde." Teenoor die besoldigingstrukture in die openbare sektor het Dr. Atmore, Adjunk-tegniese direkteur, Anglo American Corporation of SA Ltd., die punt geopper dat navorsers in die privaatsektor volgens meriete beloon word. Diegene wat bo hul makkers presteer, kan feitlik onbeperk vorder en hoë verwagtinge speel ' $n$ belangrike rol in die aansporing van navorsers om alles in die stryd te werp om sukses te behaal.

Een metode om die besoldiging van navorsers op 'n rasionele basis te plaas is om hulle bydraes tot die welvaart van die organisasie met die bydraes van produksiepersoneel te vergelyk en hulle dan in dieselfde verhouding te beloon.

Dr. Stutterheim het die verrigtinge met 'n paar prikkelende gedagtes afgesluit. Die een was dat dit te betreur is dat uitstaande senior navorsers slegs bevor-

(Vervolg op bl. 52) 